\title{
Effect of shellfish culture on phytodetritus vertical fluxes in tropical waters - southern Brazil
}

\author{
Luis A. Proença \& Carlos A. F. Schettini \\ Universidade do Vale do Itajaí - Centro de Ciências Exatas da Terra e do Mar -CCTMar \\ (Caixa Postal 360, 88302-202, Itajaí, SC, Brasil) \\ e-mail:proenca@univali.rct-sc.br
}

- Abstract: Mussel culture is an expanding activity in shallow and sheltered bays along the coast of Santa Catarina, southern Brazil. Although mussel culture generates benefits, several environmental impacts are associated with this kind of activity. Its success depends on. factors which include the environmental impact and the carrying capacity of the system. One conspicuous effect of mussel culture is the enhancement of vertical particle flux to the bottom sediment and depletion of water column phytoplankton biomass. Phytodetritus vertical fluxes was evaluated in a mussel culture area by collecting particles with sediment traps and analysing plant pigment by high performance liquid chromatography (RF-HPLC). Results showed that mussel culture, in average, enhances almost 5 times the vertical phytodetritus flux as compared to the reference site. Pheophorbide like pigments were the main chlorophyll- $a$ degradation products collected by the traps. Given the high phytodetritus production, compared to the low water column phytoplankton biomass observed, it is suggested that allocthonous phytoplankton advected to the cultured area is an important process to sustain the mussel growth in the area.

- Resumo: O cultivo de moluscos ao longo da costa de Santa Catarina tem crescido de forma acelerada nos últimos anos. Embora os benefícios sejam muitos, vários tipos de impactos ambientais podem ser decorrentes do cultivo de moluscos. Desta forma, o sucesso da atividade depende de fatores que envolvem a capacidade suporte do meio e do grau que o ambiente é impactado. Um dos mais evidentes impactos associados ao cultivo de moluscos marinhos é o aumento da taxa de fluxo vertical de partículas associado a redução da biomassa fitoplanctônica na coluna de água. O fluxo vertical de fitodetritos produzidos em uma área de cultivo foi avaliado por meio de análise por cromatografia líquida de alta eficiência (CLAE) de pigmentos fotossintéticos e produtos de degradação do material coletado por armadilhas de sedimento. Os resultados indicam que o cultivo de moluscos aumenta em média 5 vezes o fluxo vertical de fitodetritos, sendo que a maior parte da degradação da clorofila- $a$ ocorre na forma de feoforbídeos. Dado o expressivo fluxo vertical de fitodetritos, comparado a pequena biomassa na coluna de água, sugere-se que o fitoplâncton alóctono, trazido por processos advectivos, é importante para a manutenção do crescimento dos moluscos na área estudada.

- Descriptors: Pheopigment, HPLC, Detritus, Mussel culture, Sedimentation.

- Descritores: Detrito, Cultivo de moluscos, Sedimentação, Feopigmentos, CLAE, Águas costeiras, Santa Catarina. 


\section{Introduction}

Aquaculture has become an important activity for developing economic growth in coastal areas of Santa Catarina State, southern Brazil. During the last ten years, total mussel production increased from 190 to 6000 metric tons, making Santa Catarina state the largest cultured mussel producer in the country (EPAGRI, 1997). The production is rapidly increasing due to cultured area expansion, introduction of new technologies and species, and more investment from state government and seafarmers. The economic aspect of mussel culture in Santa Catarina is socially important as it is carried out mostly by former artizanal fishermen which have been facing a decrease in fish catch (Medeiros et al., 1997). The blue mussel Perna perna is the main cultured species, followed in a much less extension by the exotic oyster Crassostrea gigas. Culture sites along the northern coast of Santa Catarina are located in sheltered and shallow bays. Besides its benefits, environmental impacts are expected as mussel culture changes several natural features (Dhalbäck \& Gunnardson, 1981; Ottman \& Sornin, 1985; Hatcher et al., 1994; Grant et al, 1995; Dankers \& Zuidema, 1995).

The environmental impacts generated by mussel culture include: 1) the aesthetics, as culture structure changes the landscape; 2) hydrological, as culture structures modify current patterns; 3) biological, with introduction of new substrate and, in some cases, new species; 4) chemical and geological, as mussel filtration activity clears the water and enhances the rate of particle sedimentation throughout faecal material production. The last item which has been studied in different environments, most from temperate regions, was recognised to affect nutrient cycling, the water column oxygen budget and particle fluxes (e.g.: Ottman \& Sornin, op. cit.; Grant et al., op. cit.).

Mussel feeding relies on the low selective filtering process, which leads to small particle aggregation into larger faecal pellets, enhancing local vertical particle transport (Dankers \& Zuidema, $o p$. cit.). The organic matter in the aggregated material can be used as substrate for heterotrophic growth, which occurs either in the water column during settling and ressuspension, or at the sedimentwater interface (Dhalbäck \& Gunnardson, op. cit.). In some case, where currents are not strong enough to transport this material, bottom oxygen can be depleted, leading to anoxia of the sediment and the overlying water. A large fraction of this organic matter is derived from filtered phytoplankters which is added to the detritus pool. As mussel filtration is virtually continuous, the process represents an increase in the overall phytoplankton sedimentation and a loss of autotrophic water column biomass. Mussel filtering rates, food availability and its vertical flux are therefore key processes to evaluate the carrying capacity of the system and associated environmental impacts.

In this study, the effect of mussel culture on vertical fluxes of phytoplankton derived detritus was evaluated on a seasonal basis in a tropical coastal area. Vertical fluxes were estimated by sediment trap experiments and phytodetritus was evaluated from the quantitative analysis of chlorophyll- $a$, some of its degradation products and carotenoids by reversed phase high performance liquid chromatography (RFHPLC) from the collected material.

\section{Study area}

The sediment trap experiments were carried out in the "Armação do Itapocoroy" Bight (AIB), located at the northern shore of Santa Catarina State, southern Brazil (Fig. 1). The south-eastern portion of the bight is sheltered from the direct influences of southerly winds and waves, related to the passage of cold fronts, making the region suitable for culture. The area is shallow, reaching up to $10 \mathrm{~m}$ depth at its outermost portion.

The regional tide pattern is semi-diurnal with slight inequalities. The mean range is about $0.8 \mathrm{~m}$, varying from 0.6 to $1.2 \mathrm{~m}$ during the neap and spring tides. Tide currents may reach up to $0.3 \mathrm{~m} \mathrm{~s}^{-1}$ during spring tides, but are generally slower than $0.2 \mathrm{~m} \mathrm{~s}^{-1}$. The circulation in the bight is strongly driven by winds, which usually comes from the NE sector. The salinity is generally high, but during periods of high riverine runoff, mainly from the Itajai-Açu Estuary located about $20 \mathrm{~km}$ to the South, it can decrease to less than 25. Water temperature shows a seasonal pattern and ranges from 18 to $28^{\circ} \mathrm{C}$ during the year.

Total annual mussel production in 1997 was estimated at 1,300 tons, distributed in an area of approximately $4,000 \mathrm{~m}^{2}$, where about $95 \%$ is used to culture the Perna perna (Mytilidae) and the remaining 5\% reserved to culture the oyster Crassostrea gigas. Mussels are cultured using the long-line method, where individuals are fixed on a vertical rope, sustained by buoys attached to a long horizontal line. These lines are perpendicular to the coast to minimise the stress generated by swells. Phytoplanktonic biomass and production in the culture area is relatively low and dominated by diatoms. Nutrient inputs comes directly to the area from small creeks and from the Itajai-Açu Estuary. These overall conditions enable a high mussel growth rate in the area. Commercial size $(7 \mathrm{~cm})$ of $P$. perna is attained in about 7 months. 


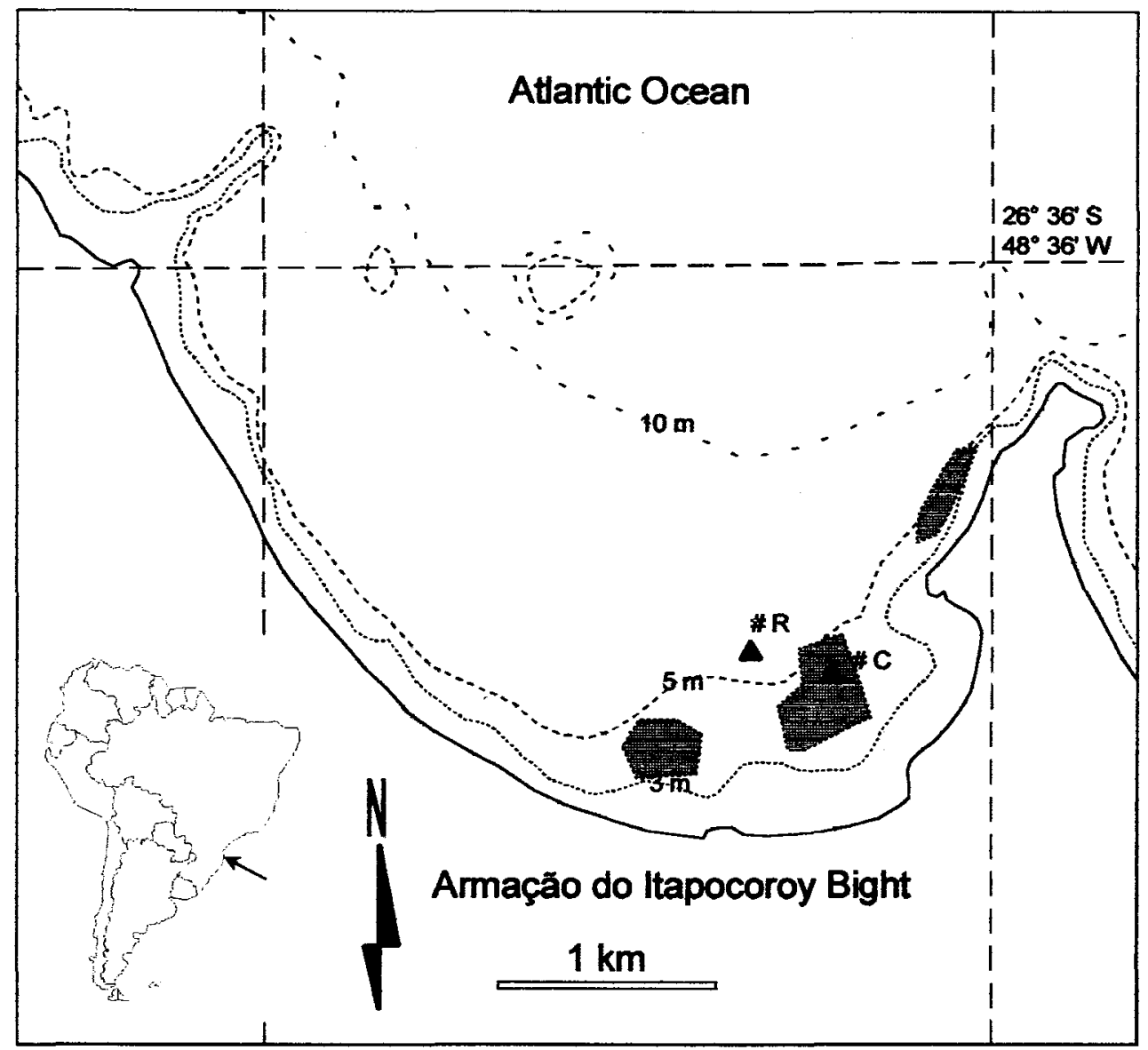

Fig. 1. Armação do Itapocoroy Bight showing culture areas (dark hatched) and trap deployment sites (R reference and $\mathrm{C}$ - culture).

\section{Materials and methods}

Sediment trap experiments were carried out every two months, during neap tide periods at two sites: under the culture (\#C) and outside (reference site, \#R) from February to December 1996 (Fig. 1). The traps, installed and recovered by divers, consisted of two PVC tubes, attached to a submersed buoy at $1 \mathrm{~m}$ above the bottom (Fig. 2). Local depth ranged from 4 to $6 \mathrm{~m}$ at station \#C and station \#R, respectively. The trap system was adapted from Larson et al. (1986) and measured $20 \mathrm{~cm}$ in height and $4 \mathrm{~cm}$ in width, with a ratio of 5:1 (Schettini et al., 1997). After 25 hours of deployment (two tidal cycles), the traps were sealed under water and brought to the laboratory within approximately one hour for sample fractionation.

The trapped material was transferred to a beaker and the volume adjusted to $200 \mathrm{ml}$. Under magnetic stirring, four to five sub-samples were taken using a syringe like device. The quartered material was retained on Whatman glass fibber GF/F by filtration under gentle pressure. Total trapped material was estimated by weighing the filters prior and after filtration. In situ trapping reproducibility was previously tested using four cylinders and showed satisfactory results (Schettini at al., 1997). The efficiency of the subsampling protocol described above was also checked and generally showed little variation among aliquots (i.e. variation coefficient usually around 3 and always less than $10 \%$ ).

From a subsample, plant pigment concentration, chlorophyll- $a$ (chl- $a$ ), its degradation products and some carotenoids were determined by reversed-phase liquid chromatography (RF-HPLC). Before grinding the filters to extract the pigments, they were soaked in 2 or $3 \mathrm{ml}$ of $90 \%$ aqueous acetone solution and left overnight in the freezer. Although this procedure may cause incomplete extraction, and better methods, such as sonication could be used, it reduces degradation of chl-a (Wright et al., 1997). The chromatography was carried out according to Wright et al. (1991). The three solvent gradient elution occurred in a FLDODS $4 \mu \mathrm{m}$ column $(4.5 \mathrm{~cm} \times 4.5 \mathrm{~mm}$, Shimadzu) as shown in Table 1. 


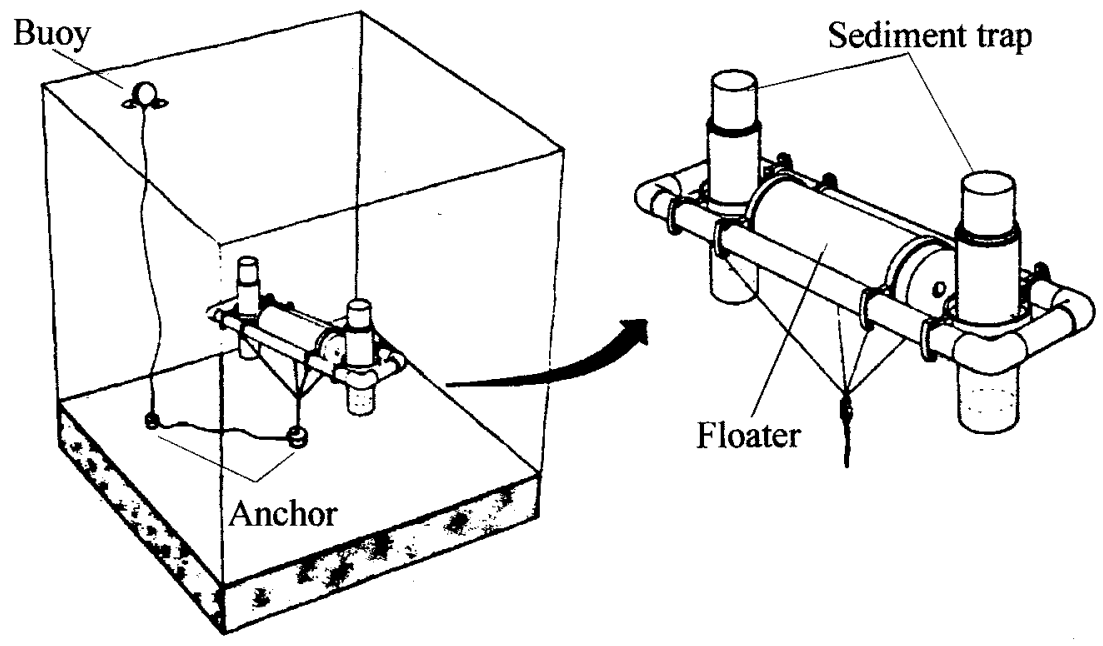

Fig. 2. The sediment trap system, after Larsson et al., 1986.

Table 1. Gradient program for RF-HPLC analysis

\begin{tabular}{r|c|c|c|c|c}
\hline \hline $\begin{array}{c}\text { Time } \\
(\min )\end{array}$ & $\begin{array}{c}\text { Flux } \\
\left(\mathrm{ml} \mathrm{m}^{-1}\right)\end{array}$ & $\begin{array}{c}\mathrm{A} \\
(\%)\end{array}$ & $\begin{array}{c}\mathrm{B} \\
(\%)\end{array}$ & $\begin{array}{c}\mathrm{C} \\
(\%)\end{array}$ & $\begin{array}{c}\mathrm{D} \\
(\%)\end{array}$ \\
\hline \hline 0 & 1 & 100 & 0 & 0 & 0 \\
\hline 3 & 1 & 0 & 90 & 0 & 10 \\
\hline 18 & 1 & 0 & 18 & 80 & 2 \\
\hline 20 & 1 & 0 & 90 & 0 & 10 \\
\hline 30 & 1 & 100 & 0 & 0 & 0 \\
\hline
\end{tabular}

A: methanol : $1 \mathrm{M}$ ammonium acetate (8:2)

B: acetonitrille

C: ethyl acetate

D: water

Before injecting a subsequent sample, the chromatographic initial condition was obtained by flushing the column with solvent A (methanol: $1 \mathrm{M}$ ammonium acetate, 8:2) for 10 minutes. The HPLC equipment consisted in a Shimadzu ${ }^{(8 C 10}$ system composed by a quaternary solvent delivery module, a Rheodine $^{\circledR}$ manual injector with a $100 \mu \mathrm{l}$ sample loop, a diode array detector $(200-600 \mathrm{~nm})$ and a spectrofluorometer, set at 407 and $607 \mathrm{~nm}$ of excitation and emission, respectively. The system was controlled by a Shimadzu ${ }^{\circledR}$ CBM $10 \mathrm{~A}$ controller and data acquired by a personal computer loaded with the Shimadzu ${ }^{\otimes}$ LC10 software. Chl- $a$ peak identification and its response factor was obtained injecting pure chl- $a$ from Sigma Co. standardised by spectrophotometry using the trichromatic equation from Jeffrey \& Humprey (1975).

Other chlorophyll and some carotenoid retention times were obtained analysing samples from cultured algae Skeletonema costatum (diatom), Amphidinium carterae (dinoflagellate) and Tetraselmis suecica (green algae, Proença, 1997). Peak identification was confirmed by their elution order and spectral characteristics. Carotenoid concentration was estimated using their specific absorption coefficient (Mantoura \& Llewelyn, 1983; Descy \& Métens, 1996). Fluorescent degradation products eluting prior and after chl- $a$ were separated into two main groups: pheophorbides and pheophytins, respectively (Barlow et al., 1993). Chl- $a$ degradation product concentrations were estimated from the fluorescence response of acidified chl- $a$ (pheophytin- $a$ ). The fluorometric response was assumed to be the same for all degradation products considered. To calculate the concentration of the degradation products, a factor was applied to convert chl- $a$ mass loss $(\mathrm{MW}=893,5)$ to pheophorbide like $(M W=592,7)$ and pheophytin like $(M W=871,2)$. The fluxes $Q_{\mathfrak{t}}$ (in $\mathrm{mg}$ day $^{-1}$ ) were calculated as follows:

$$
Q_{t}:\left(f A_{p}\left(M W_{p} / M_{c h l ~ a}\right) v_{e} /\left(v_{f} v_{i}\right)\right) 0.96 \text {, }
$$

where $\mathrm{f}$ is the pheophytin- $a$ fluorescent response factor, $A_{p}$ is the chromatographic area of pigment $p$ in $\mu \mathrm{V} \mathrm{s}{ }^{-1}, \mathrm{MW}$ is the molecular weight of $\mathrm{p}$ and of pheophytin- $a, \mathrm{v}_{\mathrm{e}}$ is the extract volume in $\mu \mathrm{l}, \mathrm{v}_{\mathrm{f}}$ is the total trapped volume in 1 and $v_{i}$ is the injected volume in $\mu \mathrm{l}$. The flux equivalent of the area of the trap $\left(1.52 \times 10^{-3} \mathrm{~m}^{-2}\right)$ was then converted to $\mathrm{m}^{-2}$.

\section{Results}

Figure 3 shows a typical chromatogram from trap samples. Several unidentified peaks were observed in both absorbance and fluorometric chromatograms, turning the identification difficult for some pigments. The absorbance chromatograms were particularly complex in the region closed to fucoxanthin retention time, between 7 to 13 minutes. The complexity was related to the presence of several carotenoid degradation products with similar spectral characteristics to their parent pigments. Another source of bias included the presence of pheophorbides eluting in this region. Although these pigments do not have a strong absorbance at $440 \mathrm{~nm}$ (Fig. 4), the high concentration in the samples 
interferes in the absorbance of carotenoids eluting at a similar chromatographic retention time. On the other hand, fluorometric chromatograms were easier to interpret once they only registered chlorophylls and degradation products. Carotenoids do not fluoresce, therefore the fluorescent chromatogram appears much clear (Rowan, 1989).

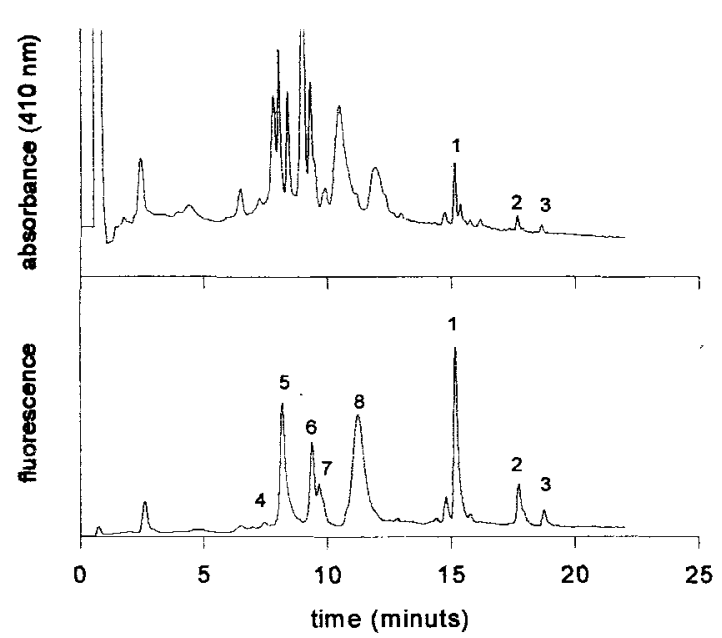

Fig. 3. Pigment separation by RF-HPLC from a 24 hours trap sample under culture $(23 / 08 / 96)$, showing chlorophyll- $a$ (1), pheophytins (2 and 3 ) and pheophorbides $(4,5,6,7,8)$.

Degradation products were separated into two main groups. Five major pigments eluting between chlorophyll $\mathrm{c} 2$ and chl- $a$, (within 5 and 15 minutes), with maximum absorption in the eluant around $407 \mathrm{~nm}$, were named pheophorbides like pigments according to their elution order (Barlow et al., 1993). They were present in all samples but varied in concentration. The other group included two pheophytin (magnesium free) pigments which eluted after chl-a. Diode array spectra (350 $600 \mathrm{~nm}$ ) in the eluant from some of these pheopigments are shown in Figure 4 . Among pheophorbides and pheophytins, the former were the dominant chl- $a$ degradation products in all trap samples, either from the culture or reference site.

Vertical fluxes of pigments are depicted in Figure 5. Results indicate that mussel culture increased the overall pigment vertical flux, but the proportion in which it occurs depends on the pigment or period of the year analysed. Chl- $a$ fluxes ranged from 1.2 to $27.0 \mathrm{mg}$ chl- $a \mathrm{~m}^{-2} \mathrm{~d}^{-1}$ under the culture and from 0.4 to $5.6 \mathrm{mg}$ chl- $a \mathrm{~m}^{-2} \mathrm{~d}^{-1}$ at the reference site. Just in one occasion, in April, the flux of chl- $a$ at the reference site was higher than under the culture array. Mussel culture enhanced the vertical chl- $a$ flux up to 11 times as measured in
February 1996. Apparently, a seasonal signal was detected with lower fluxes in June and August, austral winter months. Although this behaviour may be related to other seasonal variables, such as phytoplankton biomass or mussel growth rate, data are not sufficient in number to obtain a significant correlation.

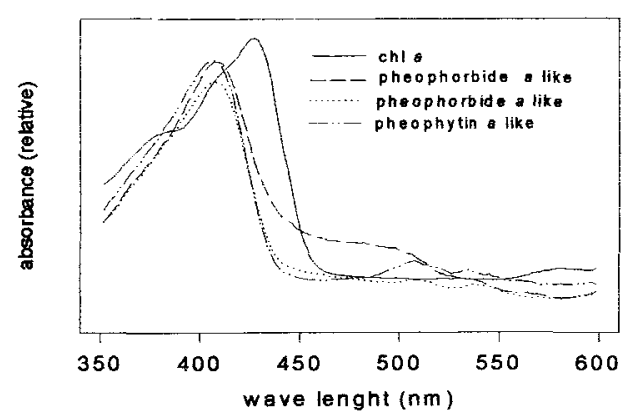

Fig. 4. Absorption spectral in eluant of chlorophyll-a, pheophorbides and pheophytins separate by RFHPLC from trap samples.

Fluxes of magnesium free chl- $a$ degradation products were always higher under the mussel culture. Fluxes of pheophorbides ranged from 4.6 to $55.4 \mathrm{mg} \mathrm{m}^{-2} \mathrm{~d}^{-1}$, and from 0.5 to $6.6 \mathrm{mg} \mathrm{m}^{-2} \mathrm{~d}^{-1}$ at the culture and reference sites, respectively. As shown in Figure 5, these products, but pheophytins, were the main fluorescent pigment found in trap samples under the culture with values and even higher than chl-a. This behaviour was slightly different at the reference site, where chl- $a$ fluxes were higher in April, June and December. Pheophytins accounted for a smaller portion of total pheopigment fluxes both under the culture and the reference site.

Table 2 summarises the results obtained during the experiments. It is evident that the fluxes of all pigments analysed were increased due to the culture, but not at the same proportion. While pheophorbide flux was in average 8 times higher under the culture, pheophytins had an increment of only $50 \%$. Chl- $a$ flux was in average 3 times higher under the culture site. The effect of the culture is evident in the total particle vertical flux as well, which averaged 44.8 and $110.3 \mathrm{~g} \mathrm{~m}^{-2} \mathrm{~d}^{-1}$ at the reference and culture sites, respectively. From these values, we estimate the average chl- $a$ and pheopigment content in the settling particles from the two sites. For chl- $a$ a quite similar value was observed between the reference and culture sites, 5.4 $\times 10^{-3}$ and for $6.3 \times 10^{-3} \%$, respectively. On the other hand, pheopigment (pheophorbides plus pheophytins) content as percentage of the total settling particles fluxes, was two times higher under the culture. 

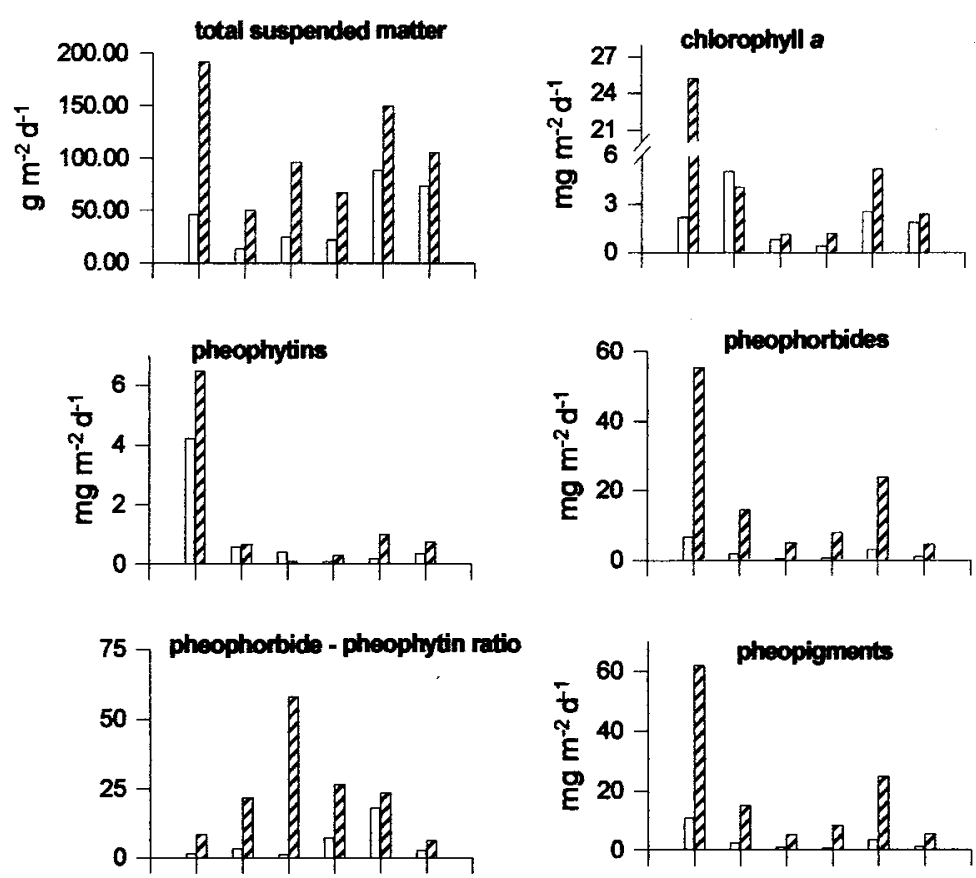

feb apr jun aug oct dec

months

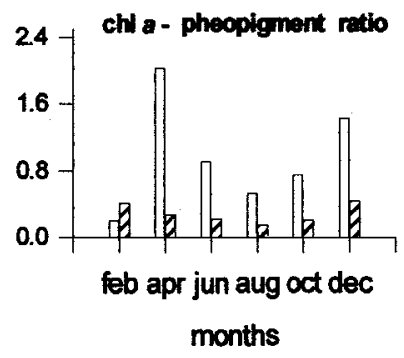

Fig. 5. Monthly fluxes of total particulate matter, chlorophyll-a, pheophytins, pheophorbides, total pheopigments and the ratios of pheophytins to pheophorbides and chlorophyll- $a$ to pheopigments obtained by trap samples at culture area and at the reference sites at Armação do Itapocoroy Bight during 1996.

Table 2. Averaged pigment fluxes and pigment ratios obtained from trap samples in side of culture area and at the reference site.

\begin{tabular}{ccccccc}
\hline \hline Site & $\begin{array}{c}\text { Total } \\
\text { Suspended } \\
\text { matter } \\
\mathrm{g} \mathrm{m}^{-2} \mathrm{~d}^{-1}\end{array}$ & $\begin{array}{c}\text { Chl-a } \\
\mathrm{mg} \mathrm{m}^{-2} \mathrm{~d}^{-1}\end{array}$ & $\begin{array}{c}\text { pheophorbides } \\
\mathrm{mg} \mathrm{m}^{-2} \mathrm{~d}^{-1}\end{array}$ & $\begin{array}{c}\text { pheophytin } \\
\mathrm{mg} \mathrm{m}^{-2} \mathrm{~d}^{-1}\end{array}$ & $\begin{array}{c}\text { pheopigment } \\
\mathrm{mg} \mathrm{m}^{-2} \mathrm{~d}^{-1}\end{array}$ & $\begin{array}{c}\text { Chl-a } / \\
\text { pheopigment }\end{array}$ \\
\hline Culture (c) & 110.3 & 6.9 & 18.5 & 1.5 & 20.1 & 0.3 \\
Reference (r) & 44.8 & 2.4 & 2.3 & 1.0 & 3.3 & 0.7 \\
$\mathrm{c} / \mathrm{r}$ & 2.5 & 2.9 & 8.0 & 1.5 & 6.1 & \\
\hline
\end{tabular}

\section{Discussion}

Mussels cause the deposition of a great amount of suspended matter in which phytodetritus is included. Generally, methods applied to evaluate chl- $a$ concentration in the water column, such as the spectrophotometric and fluorometric, are used to quantify the phytodetritus portion in the settling material. This procedure has some drawbacks due to interference of degradation products, which are avoided with the use of HPLC method. In this study, apart from chl- $a$, we have found several degradation 
products in the settling material produced during mussel filtration. The most common products of the degradation of the chlorophylls are the $\mathrm{Mg}$-free derivatives, pheophytins or pheoporphyrins, formed rapidly when the $\mathrm{pH}$ is lowered. Loss of the phytyl chain by hydrolysis is another common degradation route, forming chlorophyllide. When both the phytyl chain and $\mathrm{Mg}$ are lost, the product is a pheophorbide (Rowan, 1989). While pheophorbides are major degradation products generated during animal grazing (Vernet \& Lorenzen, 1987), pheophytin- $a$ can play a role in the photosynthesis and is always present as a trace pigment in natural populations (Porra et al., 1997). Although pheophorbides can dominate the pheopigment content in seawater, significant amount of pheophytin can be produced by some specific grazers (Vernet \& Lorenzen, op. cit.). Our results show that pheophorbides are the major degradation product under the mussel culture and pheophytins the minor, being this degradation product found in up to a 58 times smaller concentration, as observed in June.

In contrast to the data obtained by fluorometric detection, not much can be inferred from the analysis of the absorbance chromatogram of the trapped material due to the large concentration of degradation products. In samples from the water column, usually with a low level of degradation products, useful information such as the dominant algal group, can be easily obtained by the analysis of the accessory carotenoids given by the absorbance chromatogram. But carotenoids, as chlorophylls, can be degraded during mussel filtration and several products formed, increasing the complexity of the chromatographic signal, as also observed in this study. Although we used a diode array detector, which could furnish an additional information, the absorption spectra within carotenoids or their degradation products are quite similar. Therefore, they must be chromatographically well resolved to be properly analysed. Apparently, fucoxanthin was a dominant carotenoid in the samples. This pigment is a marker used for diatoms (i.e. Mantoura \& Llewellyn, 1983) and its presence indicates that this group is among the main algae filtered by the cultured mussel. The dominance of diatoms within the water column has been previously observed by the distribution of fucoxanthin, confirmed by microscopy (unpublished data).

Several factors may have affected the pigment vertical flux distribution observed during this study (Fig. 5). They include: particle availability, amount and quality, mussel biomass and filtration rate, advection and ressuspension, among others. The Itajai-Açu River, located $20 \mathrm{~km}$ southwards, has been identified as an potentially important source of particles and nutrients to the bight. The dispersion of the Itajaí-Açu River plume is largely driven northwards (Schettini et al., 1998). Thus, the water quality of AIB is expected to vary according to ItajaíAçu River runoff pulses and cross shelf exchange, affecting the observed temporal vertical particle fluxes. The extent of these meso-scale process is still difficult to assess. However, salinity revealed low impact, and showed little variation during the sampling days, ranging between 31 and 35 . Most probably, the effect of the Itajai-Açu River and other estuaries occurs in a more indirect way.

Another factor which may have influenced the temporal variation of the vertical fluxes was bottom ressuspension. Sediment granulometric measurements revealed a low percentage of fine sediments, with a predominance of sand and a high percentage of carbonates (Schettini, unpublished data). This indicates that although vertical fluxes are enhanced below the mussel culture array, particles may be ressuspended to the water column and flushed out by advection. Ressuspension might have been the cause for the extreme high vertical flux observed in February, as the experiment was carried out under high external physical energy, with strong winds and long period waves.

The effect of ressuspesion on the mussel feeding must be addressed in the future to make possible a better estimation of the fate and origin of the particles. On the other hand, the present data may be used to formulate some hypotheses. The growth rate of $P$. perna at AIB is high, attaining commercial size (e.g. $7 \mathrm{~cm}$ length) in approximately seven months. Food availability has been identified as one of the most important factor for this rapid growth. The high filtration rates and food requirements certainly contributes to the relatively low chl- $a$ values found in the water column at Armação do Itapocoroy during this study, which averaged $1.0 \mathrm{mg} \mathrm{m}^{-3}(\mathrm{n}=40)$. Averaged chl- $a$ plus pheopigment flux under the culture attained $27.0 \mathrm{mg}$ $\mathrm{m}^{-2} \mathrm{~d}^{-1}$. This value is about 5 times greater than the averaged instantaneous chl- $a$ concentration in the water column $\left(1.0 \mathrm{mg} \mathrm{m}^{-2}\right.$ and $6 \mathrm{~m}$ depth). Even considering a fast phytoplankton doubling rate, e.g. $\mu_{\max }: 1.0 \mathrm{~d}^{-1}$ for eutrophic coastal waters (Parsons $e t$ al., 1984), in situ production would not be enough to sustain the observed phytodetritus vertical flux. If in situ production is not sufficient, the phytoplankton settled biomass must come from elsewhere. Hydrological measurements showed that water advection is a major process at AIB (Schettini et al., 1997). It can be inferred that this process is responsible for influx of allocthonous phytoplankton biomass to AIB, which will sustain the high mussel growth rates and phytodetritus fluxes observed. On 
the other hand, ressuspension caused by wave action may also play a role in the process. Particles already settled could be ressuspended and filtered, thus diminishing the importance of the allocthonous input of particles.

It is important to point out that the pigments analysed are not the only degradation products of chl- $a$. Several other pathways are possible, including the production of colourless products (Svec, 1978). Therefore, the phytodetritus vertical flux may have been even greater than the sum of those pigments analysed. Comparable results were obtained by Dahlbäck \& Gunnarsson (1981) investigating vertical fluxes under a similar mussel culture at the Swedish west coast in a shallow, 8-13 m deep, bay. Their calculated ratios referred to the fall season in a temperate ecosystem. Chl- $a$ averaged vertical fluxes at AIB under the culture and reference sites were approximately 3 times higher than that measured by Dhalbäck \& Gunnardson (op. cit.), even though the ratio between culture and reference was quite similar as well the ratio of chl- $a$ / pheopigment.

Our results showed that mussel culture affects the chl- $a$ to pheopigment (mainly pheophorbides) ratio in the particulate matter changing it from $1: 1.4$ to $1: 3$. This change is even greater when compared to the averaged value of 13:1 found in the water column. This finding indicates that the mussel culture at AIB has an impact not only on the bulk of particle flux, but in its quality as well. This fact has an implication on chl- $a$ measurements within culture areas based on fluorometric or spectrophotometric methods. Both standard methods are biased by the presence of degradation products (Mantoura et al., 1997). Therefore, an overestimation of water column chl- $a$ at mussel culture areas is to be expected. If proper measurements of the chl- $a$ to degradation products are taken within the area, they could be used as indicative for mussel derived phytodetritus.

\section{Acknowledgements}

We thank the personnel from the "Centro Experimental de Maricultura" at AIB, specially to Adriano Marenzi and Gilberto Manzoni for their help on carrying out this research, Marcio Silva and José R. Dernil, for their help on collecting and processing the samples and two anonymous reviewers for their comments on the manuscript. This work was supported by a FAP/FACIMAR UNIVALI grant. Luis Proença received a CNPq scholarship.

\section{References}

Barlow, R. G.; Mantoura, F. A.; Gouch, M. A. \& Fileman, T. W. 1993. Pheopigment distribution during the 1990 spring bloom in the northeastern Atlantic. Deep-Sea Res., 40(1112):2229-2242.

Dankers, N. \& Zuidema, D. R. 1995. The role of mussel (Mytilus edulis L.) and mussel culture in Dutch Wadden Sea. Estuaries, 18(1A):71-80.

Descy, J. \& Métens, A. 1996. Biomass-pigment relationship in potamoplankton. J. Plankt. Res., 18(9):1557-1566.

Dhalbäck, B. \& Gunnarsson, L. A. H. 1981. Sedimentation and sulphate reduction under a mussel culture. Mar. Biol., 63: 269-275.

EPAGRI. Empresa de Pesquisa Agropecuária e Extensão Rural de Santa Catarina S.A. 1997. Cadeias produtivas. Relatório. Florianópolis, EPAGRI.

Grant, J. A.; Hatcher, A., Scott; D. B., Pocklington, P.; Schafer, C. T. \& Winters, G. V. 1995. A multidisciplinary approach to evaluating impacts of shellfish aquaculture on benthic communities. Estuaries, 18(1A):124-144.

Hatcher, A.; Grant, J. A. \& Scott, D. B. 1994. The effects of suspended mussel culture (Mytilus spp) on sedimentation, benthic respiration and sediment nutrient dynamics in a coastal bay. Mar. Ecol. Progr. Ser., 115(3):219-235.

Jeffrey, S. W. \& Humphrey, G. F. 1975. New spectrophotometric equations for determining chlorophylls $a, b, c_{1}$ and $c_{2}$ in higher plants, algae and natural phytoplankton. Biochem. Physiologia Pl., 167:191-194.

Larsson, U.; Blomqvist, S. \& Abrahamsson, B. 1986. A new sediment trap system. Mar. Ecol. Progr. Ser., 31:205-207.

Mantoura, F. A.; Jeffrey, S. W.; Llewellyn, C. A.; Claustre, H. \& Morales, C. E. 1997. Comparison between spectrophotometric, fluorometric and HPLC methods for chlorophyll analysis. In: Jeffrey, S. W.; Mantoura, R. F. C. \& Wright, S. W. eds. Phytoplankton pigments in oceanography. Paris, UNESCO. p. 361-380. 
Mantoura, F. A. \& Llewellyn, C. A. 1983. The rapid determination of algal chlorophyll and carotenoid pigments and their breakdown products in natural waters by reverse-phase high performance liquid chromatography. Anal. Chim. Acta., 15(2):297-314.

Medeiros, R. P.; Polette, M.; Vizinho, S. C.; Macedo, C. X. \& Borges, J. C. 1997. Diagnóstico sócioeconômico e cultural nas comunidades pesqueiras artesanais do litoral centro-norte do estado de Santa Catarina. Notas Técnicas Facimar, 1:33-42.

Ottmann, F. \& Sornin, J. 1985. Observations on sediment accumulation as a result of mollusc culture systems in France. In: INTERNATIONAL SYMPOSIUM ON UTILISATION OF COASTÁL ECOSYSTEMS: PLANNING, POLLUTION AND PRODUCTIVITY. Rio Grande, 1982. Proceedings. Rio Grande, FURG. p. 329-337.

Parsons, T. R.; Takahashi, M. \& Hargrave, B. 1984. Biological oceanographic processes. Oxford, Pergamon Press. 330p.

Porra, R. J.; Pfündel, E. E. \& Engel, N. 1997. Metabolism and function of photosynthetic pigments. In: Jeffrey, S. W.; Mantoura, R. F. C. \& Wright, S. W. eds. Phytoplankton pigments in oceanography. Paris, UNESCO. p. 85-126.

Proença, L. A. 1997. Separação de pigmentos fotossintéticos do fitoplâncton por meio de cromatografia líquida de alta eficiência (CLAE). Notas Técnicas Facimar, 1:23-31.

Rowan, K. S. 1989. Photosynthetic pigments of algae. Cambridge, Cambridge Univ. Press. $334 \mathrm{p}$.
Schettini, C. A. F.; Resgalla Jr., C. \& Kuroshima, K. N. 1997. Avaliação preliminar da taxa de sedimentação na região de cultivo de moluscos na Enseada da Armação, SC. Notas Técnicas Facimar, 1:1-7.

Schettini, C. A. F.; Kuroshima, K. N.; Pereira Filho, J.; Rörig, L. R. \& Resgalla Jr., C. 1998. Oceanographic and ecological aspects of the Itajaí-Açu River plume during a high discharge period. Anais Acad. Bras. Ciênc., 70(2):335351.

Svec, W. A. 1978. The isolation, preparation, characterisation and estimation of chlorophylls and the bacteriochlorophyll. In: Dolphin, D. ed. The Porphyrins. New York, Academic Press. p. 341-399.

Vernet, M. \& Lorenzen, C. J. 1987. The relative abundance of pheophorbide- $a$ and pheophytin- $a$ in temperate marine waters. Limnol. Oceanogr., 32(2):352-358.

Wright, S. W.; Jeffrey, S. W.; Mantoura, F. A.; Llewellyn, C. A.; Bjornland, T.; Repeta, D. \& Whelsmeyer, N. 1991. Improved HPLC method for the analysis of chlorophylls and carotenoids from marine samples. Mar. Ecol. Progr. Ser., $77(2-3): 183-196$.

Wright, S. W.; Jeffrey, S. W. \& Mantoura, F. A. 1997. Evaluation of methods and solvents for pigment extraction. In: Jeffrey, S. W.; Mantoura, R. F. C. \& Wright, S. W. eds. Phytoplankton pigments in oceanography. Paris, UNESCO. p. 261-282.

(Manuscript received 26 November 1997; revised 26 October 1998; accepted 10 December 1998) 